\title{
Management of Incidental Amyand Hernia With A
}

\section{Case Report}

\author{
Tolga Kalayci ${ }^{*}$, Ümit Haluk Iliklerden \\ Department of General Surgery, Yuzuncu Yil University Faculty of Medicine, V an,Turkey
}

\begin{abstract}
The presence of appendix vermiformis in inguinal hernia is known as Amyand hernia. Amyand hernia is a rare condition estimated to account for approximately $1 \%$ of all inguinal hernias. In our case we want to show our approach to incidental Amyand hernia.

An 80-year-old male patient was received at urology service at Van Yuzuncu Yil University Department of Medicine because of prostatic symptoms. There were comorbid factors like hypertension,chronic obstructive lung disease and geriatric age. On surgery with spinal anesthesia, surgeons invited us to evaluate his left inguinal hernia. We evaluated hernia and saw distal ileal segments, proximal right colonic segments and inflamme appendix at hernia defect. Because of appendix inflammation we performed appendectomy. Hernia was repaired with mesh. We put a drain at surgery area. At postoperative first day, the patient discharged with drain. The fifth day of post-surgery, the drain was pulled out. At the time of 1 st and 3 rd month check of the patient, there was no problem about surgery.

Amyand hernia is one of the rare conditions encountered by the surgeon during hernia surgery. The surgeon must know the Rosanoff and Bassoon Classification of Amyand Hernia to successfully manage Amyand hernia surgery. The surgeon also must know the situation in which case an appendectomy should be performed and in which case the mesh should be used.
\end{abstract}

Key Words: Amyand Hernia, Appendectomy, Complication, Mesh

\section{Introduction}

Amyand hernia is the presence of appendix tissue within inguinal hernia sac. It is a rare condition which is determined nearly $1 \%$ of all inguinal hernias. Amyand hernia was firstly defined by Cladius Amyand, at $18^{\text {th }}$ century, who operated 11 -year-old child for appendicitis. While performing surgery, Amyand found inguinal hernia and did appendectomy (1). Amyand hernias are mostly seen incidentally at other surgeries. Unfortunately, the appearance of Amyand hernia is rare at elective cases (2). At incidental Amyand hernia, two major problems encountered: Should we do appendectomy? And How should we repair the hernia? There are lots of proposals to answer these questions. In our case, we want to show our approach and literature's approach to incidental Amyand hernia.

\section{Case Report}

An 80-year-old male patient was received at urology service because of prostatic symptoms which were last during 3 months. There were comorbid factors like hypertension, chronic obstructive lung disease and geriatric age. However, no surgery history and laboratory pathology were determined. After tests, doctors had an open prostate surgery decision. At the operation, Because of the comorbid factors, prostate surgery was planned with spinal anesthesia. Surgeons invited us to evaluate his left inguinal hernia for simultaneously hernia surgery. We evaluated hernia and saw distal ileal segments, proximal right colonic segments and inflamme appendix at hernia defect (Fig. 1). Because of appendix inflammation we performed appendectomy. After hernia content was delivered into the abdomen, patient's hernia was repaired convenient with mesh. There was no hemorrhage during surgery, but because of comorbid factors, we put a drain at surgery area. At postoperative first day, the patient discharged with drain. The fifth day of surgery, the drain was pulled out. At the time of 1st and 3rd month check of the patient, we saw that there was no problem about surgery.

\section{Discussion}

First in 1735, King II. George's surgeon Claudius Amyand, performed right inguinal hernia repair and appendectomy for perforated appendicitis in the right inguinal sac in whom an 11-year-old male patient in

${ }^{*}$ Corresponding Author: Tolga Kalayc1, Operator Dr. at Department of Surgery, School of Medicine, Van Yuzuncu Yil University, 65080, 


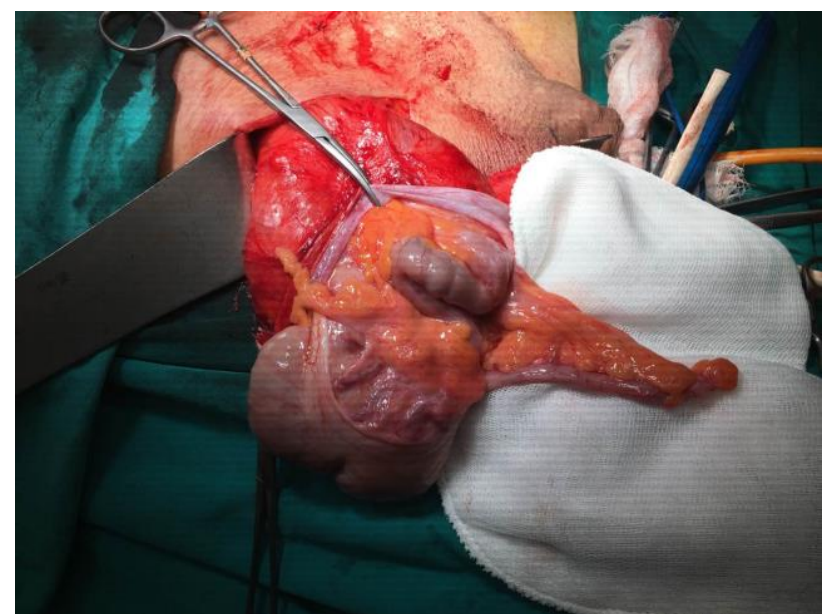

Fig. 1. Intraoperative Image of Amyand Hernia

the UK. His name has passed the literature after this operation as Amyand hernia (3). Rene Jacques Croissant de Garengeot performed the first acute appendicitis case which was published in femoral hernia sac at 1731 (4).

Amyand hernia is more common in males than females. Female patients are often in the postmenopausal period and usually have femoral hernia (5). Amyand hernia detected in the left inguinal region may be caused by situs inversus, malrotation or mobile caecum. Very few cases with left Amyand hernia have been reported in the literature (6).

Inguinal hernioplasty is among the most common surgery procedure of adult which is mostly diagnosed with anamnesis and physical exam (7). Amyand hernia constitutes $1 \%$ of all cases of inguinal hernia and $<1 \%$ of appendicitis cases have Amyand hernia (8).

In the series of Solecki et al. Amyand hernia rate was reported as $0.62 \%$ (9). Ryan et al. reported presence of Amyand hernia as $0,013 \%$, in which acute appendicitis was seen 11 of 8692 patients who underwent hernia surgery (10). Also at Priego et al's study in which 4752 patient attended, the rate of appendicitis in the inguinal hernia sac was $0,126 \%$ (11).

Although there is no clear information about Amyand hernia formation, it is believed that increased intraabdominal pressure caused by the contraction of abdominal wall muscles compresses the mesoappendix. After that the process continues as the development of appendicitis due to inflammation and increased bacterial colonization (12).

Preoperative diagnosis of Amyand hernia is very difficult. Patients are usually operated with the diagnosis of incarcerated hernia (13). The presence of the appendix in the hernia sac can usually be detected after opening the hernia sac (14). Contrasted computed tomography (CT) is not routinely used for inguinal hernia diagnosis, but may be helpful in the diagnosis (15). Luchs et al reported two cases diagnosed by preoperative tomography (16). Weber and Kraal were diagnosed Amyand hernia in only one patient in series of 60 patients before the operation (17).Anagnostopoulou et al. reported that they diagnosed Amyand's hernia with ultrasonography at 3-month-baby before surgery (18). From all of these studies we understand that Amyand hernia is a rare condition of hernia. Unfortunalety, the cases are operated without diagnosis of Amyand hernia before surgery as in our case.

Amyand hernia and treatment protocols were divided into 4 groups by Rosanoff and Bassoon (Table 1) (19). Our case was Type II for Rosanoff and Bassoon classification.

At the introduction of our article, we aimed to find the answer to 2 questions: Should we do appendectomy? and how should we repair the hernia?

\section{-First question is 'Should we do appendectomy?'}

The answer varies from author to author. For example; Losanoff recommends appendectomy due to the higher incidence of acute appendicitis in childhood and adolescence in the presence of noninflamed appendix in hernia sac (20). At Ofili's study with 11 patients reported that he performed appendectomy to all Amyand hernia patients. Also Ofili found that there was not recurrent hernia or wound infection because of appendectomy (21). Our opinion about appendectomy is depended on condition of appendix vermiformis. If appendix vermiformis is inflame and edematous intraoperatively, appendectomy should be done. On the other hand, at normal appendix vermiformis, we recommend appendectomy because of manuel intervention. Also Anagnostopoulou et al. did not recommended appendectomy because of the length of the operation period, the presence of additional systemic disease and low risk of appendicitis in the elderly patient group (18).

\section{-Second question is 'How should we repair the hernia?'}

Sözen et. al. recommended hernia repair with mesh if appendix vermiformis was not inflame (22). Burgess et al. reported that infection-resistant biological materials could be used to prevent relapse without causing infection (23). Campanelli et al and Kahramanca et al. reported no complications about his cases, and argued that prosthetic material could be used unless infected $(19,24)$. However Priego et. al. declared a surgery site infection because of mesh usage (11).

In cases of complicated appendicitis such as suppurative inflammation and perforation, synthetic materials increase the risk of wound infection and 
Table 1. Rosanoff and Bassoon Classification of Amyand Hernia

\begin{tabular}{|c|c|c|}
\hline Classification & Explanation & Suggested Treatment \\
\hline Type 1 & Normal appendix vermiformis. & $\begin{array}{c}\text { Reduction of appendix } \\
\text { vermiformis, hernia repair with mesh. }\end{array}$ \\
\hline Type 2 & Acute appendicitis without abdominal sepsis. & $\begin{array}{l}\text { Appendectomy from hernia incision, } \\
\text { anatomically repair of hernia. }\end{array}$ \\
\hline Type 3 & Acute appendicitis with abdominal sepsis. & $\begin{array}{l}\text { Appendectomy laparotomically, } \\
\text { anatomically repair of hernia. }\end{array}$ \\
\hline Type 4 & $\begin{array}{l}\text { Acute appendicitis, with or without other } \\
\text { abdominal pathology. }\end{array}$ & $\begin{array}{l}\text { Appendectomy from hernia incision } \\
\text { or laparotomically, whichever is } \\
\text { possible. }\end{array}$ \\
\hline
\end{tabular}

lead to appendix stump fistula. So that anatomic repair is preferred because of that reason $(4,9,18)$. In our case we used mesh due to the size of the defect. All of the studies from literature, appendectomy and mesh usage depend on appendix vermiformis situation and surgeon preference. But general opinion is to do appendectomy and use mesh if suitable.

\section{References}

1. Hutchinson R. Amyand's hernia. J R Soc Med 1993; 86: 104-105.

2. Shaban Y, Elkbuli A, McKenney M and Boneva D. Amyand's hernia: A case report and review of the literature. International Journal of Surgery Case Reports 2018; 47: 92-96.

3. Öztaş M, Yıldız R, Can MF, et al. Amyand's Hernia; Case Series and Our Ten Years Experience. Journal of Surgical Arts 2013; 6: 1-3.

4. Carey LC. Acute appendicitis occuring in hernias: a report of 10 cases. Surgery 1967; 31: 236-238.

5. Tanrıkulu Y, Erel S, Tanrıkulu CŞ, Taşova V, Ortaç EK. Olgu Sunumu: Amyand Herni. Akademik Acil Tip Dergisi 2011: 174-176.

6. Gupta S, Sharma R, Kaushik R. Left-sided Amyand's hernia. Singapore Med J 2005; 46: 424425.

7. Lao OB, Fitzgibbons RJ, Cusick RA. Pediatric surgery pediatric inguinal hernias, hydroceles,and undescended testicles. Surg Clin N Am 2012; 92: 487-504.

8. Ciğsar EB, Karadağ ÇA, Dokucu AI. Amyand's hernia: 11 years of experience. Journal of Pediatric Surgery Journal of Pediatric Surgery 51 2016; 1327-1329.

9. Solecki R, Matyja A, Milanowski W. Amyand's hernia: a report of two cases. Hernia 2003; 7 : 5051.

10. Ryan WJ. Hernia of the vermiform appendix. Ann Surg 1937; 106: 135-139.

11. Priego P, Lobo E, Moreno I, et al. Acute appendicitis in an incarcerated crural hernia: analysis of our experience. Rev Esp Enferm Dig 2005; 97: 707-705.
12. Johari HG, Paydar S, Davani SZN, Eskandari S, Johari MG. Left-sided Amyand hernia. Ann Saudi Med 2009; 29: 321-322.

13. Logan MT, Nottingham JM. Amyand's hernia: a case report of an incarcerated and perforated appendix withina an inguinal hernia and review of the literature. Am Surg 2000; 67: 628-629.

14. Ash L, Hatem S, Ramirez GA, Veniero J. Amyand's hernia: A case report of prospective CT diagnosis in the emergency department. Emerg Radiol 2005; 11: 231-232.

15. Maizlin ZV, Mason AC, Brown C, Brown JA. CT findings of normal and inflamed appendix in groin hernia. Emerg Radiol 2007; 14: 97-100.

16. Luchs JS, Halpern D, Katz DS. Amyand's hernia: prospective CT diagnosis. J Comput Assist Tomogr 2000; 24: 884-886.

17. Weber RV HZ, Kraal JG. Amyand's hernia: Etiologic and therapeutic implications of the two complications. Surg Rounds 1999; 22: 552-556.

18. Anagnostopoulou S, Dimitroulis D, Troupis TG, et al. Amyand's hernia: a case report. World J Gastroenterol 2006; 29: 4761-4763.

19. Kahramanca Ş, Kaya O, Güzel H, Özgehan G, Bostanc1 H, Gürsoy G. Amyand Herni ve Cerrahi: Apendektomi Gerekli mi? F1t1k onarımı nasil yapılmalı? DEÜ Tıp Fakültesi Dergisi 2013; 27: 75-80.

20. Losanoff JE, Basson MD. Amyand hernia: a classification to improve management. Hernia 2007; 12: 325-326.

21. Ofili OP. Simultaneous appendectomy and inguinal herniorrhaphy could be beneficial. Ethiop Med J 1991; 29: 37-38.

22. Sözen S, Alıcı A, Tükenmez M ve ark. Amyand fitığ1:Olgu serisi ve deneyimimiz. Ulusal Cerrahi Dergisi 2010; 26: 212-215.

23. Burgess PL, Brockmeyer JR, Johnson EK. Amyand Hernia Repaired with Bio-A: A Case Report and Review.J Surg Education 2011; 68: 6266.

24. Campanelli G, Nicolosi FM, Pettinari D, Contessini Avesani E. Prosthetic repair, intestinal resection, and potentially contaminated areas: safe and feasible? Hernia 2004; 8: 190-192 